\title{
Association of rs12255372 in the TCF7L2 gene with type 2 diabetes mellitus: a meta-analysis
}

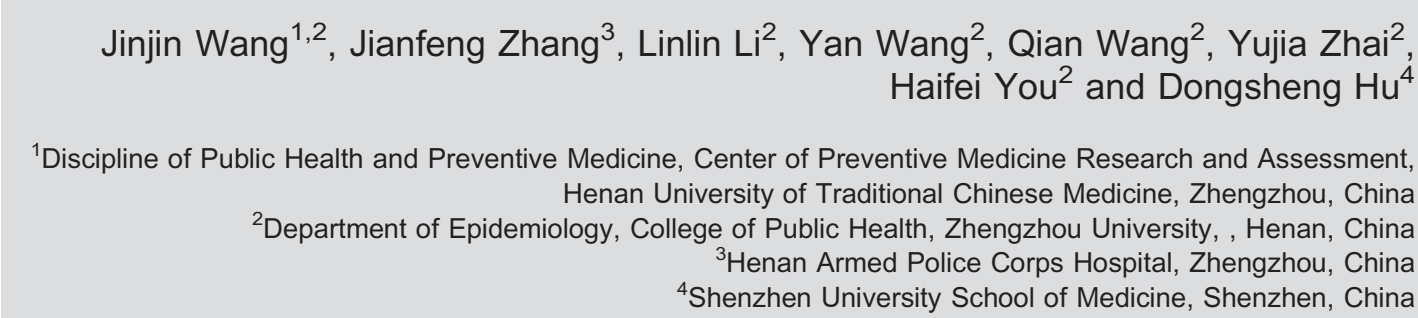

\begin{abstract}
Our objective was to evaluate the association of rs12255372 in the TCF7L2 gene with type 2 diabetes mellitus (T2DM) in the world population. We carried out a survey of the literature about the effect of rs12255372 on genetic susceptibility to T2DM by consulting PubMed, the Cochrane Library, and Embase from 2006 to 2012, and then performed a meta-analysis of all the studies in order to evaluate the association between rs12255372 and T2DM. A total of 33 articles including 42 studies (with 34,076 cases and 36,192 controls) were confirmed to be eligible and were included in the final meta-analysis: 6 studies conducted on Europeans, 14 on Caucasians, 17 on Asians, 2 on Africans, and 3 on Americans. Overall, the effect size was as follows: for the variant allele $\mathrm{T}(\mathrm{OR}=1.387,95 \% \mathrm{Cl}=1.351-1.424)$, for the TT genotype $(\mathrm{OR}=1.933,95 \% \mathrm{Cl}=1.815-$ 2.057), for the GT genotype $(\mathrm{OR}=1.363,95 \% \mathrm{Cl}=1.315-1.413)$, for the dominant model $(\mathrm{OR}=1.425,95 \% \mathrm{Cl}=1.344-$ 1.510), and for the recessive model $(\mathrm{OR}=1.659,95 \% \mathrm{Cl}=1.563-1.761)$. In summary, by pooling all available qualified data from genetic studies on rs12255372 and T2DM, we have confirmed that rs12255372 is significantly associated with susceptibility to T2DM in the global population.
\end{abstract}

Key words: Type 2 diabetes mellitus; rs12255372; SNPs; Meta-analysis

\section{Introduction}

Type 2 diabetes mellitus (T2DM) represents the most common major form of diabetes, which results from a defect in insulin secretion, almost always with a major contribution from insulin resistance. The incidence and prevalence of T2DM have reached epidemic proportions all over the world. It is predicted that there will be at least 350 million people in the world with T2DM by the year 2030, unless appropriate action is taken (1).

The mechanisms associated with T2DM have remained uncertain, but are considered to be due to a combination of lifestyle and genetic factors. Recently, research on genetic factors in T2DM has become more and more frequent and there is no doubt that the transcription factor 7-like 2 (TCF7L2) emerges as one of the strongest T2DM susceptibility genes among the possible candidate genes.
The TCF7L2 gene spans $215.9 \mathrm{~kb}$ on chromosome $10 \mathrm{q} 25$, and rs12255372, located in the intron region of $T C F 7 L 2$, contains a single $G$ to $T$ base transition at position 293. A number of epidemiological studies have evaluated the association between rs 12255372 and T2DM, but the results remain conflicting rather than conclusive (2-34; see Table 1). Two meta-analyses on the association between the TCF7L2 polymorphism rs12255372 and T2DM have been published $(35,36)$. The first, published in 2009, detected significant associations between 4 single nucleotide polymorphisms (SNPs: rs7903146, rs12255372, rs7901695, and rs11196205) in TCF7L2 and T2DM all over the world (35); however, only articles published before 2008 were included. The second meta-analysis published in 2009 focused on the alleles on 5 SNPs (rs7903146, rs12255372, rs11196205,

Correspondence: Dongsheng Hu, Shenzhen University School of Medicine, 3688 Nanhai Avenue, Nanshan District, Shenzhen, Guangdong 518060, China. Fax: +0086-(0)755-8667-1906. E-mail: dongsheng_hu@hotmail.com 
Table 1. Distribution of genotypes of the rs 12255372 polymorphism in studies of the TCF7L2 gene and susceptibility to type 2 diabetes.

\begin{tabular}{|c|c|c|c|c|c|c|c|c|c|c|c|c|}
\hline \multirow[t]{3}{*}{$\begin{array}{l}\text { First author } \\
\text { (Ref/year)/ethnicity }\end{array}$} & \multicolumn{10}{|c|}{ Genotype distribution } & \multicolumn{2}{|c|}{$\begin{array}{l}\text { Frequency of risk } \\
\text { allele }(\%)\end{array}$} \\
\hline & \multicolumn{5}{|c|}{ Cases $(n=34,076)$} & \multicolumn{5}{|c|}{ Controls $(n=36,192)$} & \multirow[t]{2}{*}{ Cases } & \multirow[t]{2}{*}{ Controls } \\
\hline & $\mathrm{N}$ & $\mathrm{TT}$ & GT & GG & $\begin{array}{c}P \\
(H W E)\end{array}$ & $\mathrm{N}$ & TT & GT & GG & $\begin{array}{c}P \\
(H W E)\end{array}$ & & \\
\hline \multicolumn{13}{|l|}{ Grant (31) 2006} \\
\hline European & 1086 & 154 & 476 & 456 & 0.258 & 795 & 71 & 316 & 408 & 0.684 & 36.1 & 28.8 \\
\hline European & 221 & 29 & 88 & 104 & 0.331 & 520 & 43 & 185 & 292 & 0.216 & 33.0 & 26.1 \\
\hline Caucasian & 344 & 62 & 144 & 138 & 0.846 & 509 & 39 & 186 & 284 & 0.546 & 39.0 & 25.9 \\
\hline \multicolumn{13}{|l|}{ Damcott (28) 2006} \\
\hline Caucasian & 137 & 24 & 67 & 46 & 0.963 & 342 & 47 & 159 & 136 & 0.961 & 42.0 & 37.0 \\
\hline \multicolumn{13}{|l|}{ Zhang (30) 2006} \\
\hline Caucasian & 1573 & 178 & 705 & 690 & 0.995 & 1947 & 140 & 772 & 1035 & 0.971 & 33.7 & 27.0 \\
\hline \multicolumn{13}{|l|}{ Scott (29) 2006} \\
\hline European & 1128 & 50 & 354 & 724 & 0.726 & 936 & 20 & 255 & 661 & 0.727 & 20.1 & 15.8 \\
\hline \multicolumn{13}{|l|}{ Cauchi (34) 2006} \\
\hline Caucasian & 2367 & 373 & 1131 & 858 & 1.000 & 2483 & 209 & 1031 & 1243 & 0.973 & 39.6 & 29.2 \\
\hline \multicolumn{13}{|l|}{ Groves (32) 2006} \\
\hline Caucasian & 2021 & 244 & 941 & 836 & 0.704 & 2491 & 214 & 1057 & 1220 & 0.782 & 35.4 & 29.8 \\
\hline \multicolumn{13}{|c|}{ Humphries (33) 2006} \\
\hline Caucasian & 1468 & 170 & 662 & 636 & 0.994 & 2489 & 188 & 994 & 1307 & 0.999 & 34.1 & 27.5 \\
\hline Asian & 841 & 68 & 350 & 423 & 0.933 & 302 & 20 & 104 & 178 & 0.668 & 28.9 & 23.8 \\
\hline African & 304 & 28 & 120 & 156 & 0.780 & 313 & 24 & 148 & 141 & 0.214 & 28.9 & 31.3 \\
\hline \multicolumn{13}{|l|}{ Horikoshi (17) 2007} \\
\hline Asian & 191 & 0 & 16 & 175 & 0.833 & 271 & 0 & 17 & 254 & 0.868 & 4.2 & 3.1 \\
\hline Asian & 657 & 1 & 41 & 615 & 0.935 & 360 & 1 & 16 & 343 & 0.246 & 3.3 & 2.5 \\
\hline Asian & 347 & 1 & 16 & 330 & 0.265 & 192 & 0 & 7 & 185 & 0.967 & 3.0 & 1.8 \\
\hline \multicolumn{13}{|l|}{ Kimber (25) 2007} \\
\hline Caucasian & 3225 & 359 & 1432 & 1434 & 0.999 & 3291 & 233 & 1323 & 1735 & 0.672 & 33.3 & 27.2 \\
\hline \multicolumn{13}{|l|}{ Marzi (26) 2007} \\
\hline Caucasian & 667 & 74 & 287 & 306 & 0.863 & 1658 & 107 & 698 & 853 & 0.0764 & 32.6 & 27.5 \\
\hline \multicolumn{13}{|l|}{ Mayans (20) 2007} \\
\hline European & 828 & 38 & 333 & 457 & 0.0651 & 786 & 28 & 236 & 522 & 0.979 & 24.7 & 18.6 \\
\hline \multicolumn{13}{|c|}{ van Vliet-Ostaptchouk (18) 2007} \\
\hline Caucasian & 492 & 59 & 217 & 216 & 0.924 & 901 & 84 & 348 & 469 & 0.256 & 34.0 & 28.6 \\
\hline Sale (23) 2007 & & & & & & & & & & & & \\
\hline African & 577 & 53 & 262 & 262 & 0.553 & 596 & 50 & 235 & 311 & 0.839 & 31.9 & 28.1 \\
\hline Guo (24) 2007 & & & & & & & & & & & & \\
\hline American & 1425 & 0 & 18 & 1407 & 0.972 & 1773 & 0 & 26 & 1747 & 0.953 & 2.8 & 1.7 \\
\hline Hayashi (21) 2007 & & & & & & & & & & & & \\
\hline Asian & 1630 & 3 & 112 & 1515 & 0.828 & 1043 & 0 & 45 & 998 & 0.776 & 3.6 & 2.2 \\
\hline Parra (27) 2007 & & & & & & & & & & & & \\
\hline American & 369 & 11 & 66 & 292 & 0.201 & 268 & 4 & 54 & 210 & 0.970 & 15.5 & 11.6 \\
\hline Bodhini (15) 2007 & & & & & & & & & & & & \\
\hline Asian & 1031 & 66 & 348 & 617 & 0.210 & 1038 & 46 & 305 & 687 & 0.272 & 23.3 & 19.1 \\
\hline Chandak (19) 2007 & & & & & & & & & & & & \\
\hline Asian & 955 & 99 & 377 & 479 & 0.160 & 399 & 22 & 134 & 243 & 0.825 & 30.1 & 22.3 \\
\hline Chang (16) 2007 & & & & & & & & & & & & \\
\hline Asian & 760 & 0 & 9 & 751 & 0.987 & 760 & 0 & 6 & 754 & 0.994 & 0.6 & 0.4 \\
\hline
\end{tabular}


Table 1. Continued.

\begin{tabular}{|c|c|c|c|c|c|c|c|c|c|c|c|c|}
\hline \multirow[t]{3}{*}{$\begin{array}{l}\text { First author } \\
\text { (Ref/year)/ethnicity }\end{array}$} & \multicolumn{10}{|c|}{ Genotype distribution } & \multicolumn{2}{|c|}{$\begin{array}{l}\text { Frequency of risk } \\
\text { allele }(\%)\end{array}$} \\
\hline & \multicolumn{5}{|c|}{ Cases $(n=34,076)$} & \multicolumn{5}{|c|}{ Controls $(n=36,192)$} & \multirow[t]{2}{*}{ Cases } & \multirow[t]{2}{*}{ Controls } \\
\hline & $\mathrm{N}$ & TT & GT & GG & $\begin{array}{c}\mathrm{P} \\
(\mathrm{HWE})\end{array}$ & $\mathrm{N}$ & TT & GT & GG & $\begin{array}{c}P \\
(H W E)\end{array}$ & & \\
\hline \multicolumn{13}{|l|}{ Sladek (22) 2007} \\
\hline Caucasian & 694 & 131 & 342 & 221 & 0.998 & 654 & 55 & 267 & 332 & 0.992 & 43.5 & 28.8 \\
\hline \multicolumn{13}{|l|}{ Miyake (14) 2008} \\
\hline Asian & 465 & 1 & 28 & 436 & 0.745 & 323 & 0 & 11 & 312 & 0.953 & 3.2 & 1.7 \\
\hline Asian & 559 & 2 & 48 & 509 & 0.753 & 565 & 0 & 27 & 538 & 0.844 & 4.8 & 2.4 \\
\hline Asian & 1146 & 2 & 76 & 1068 & 0.869 & 949 & 1 & 42 & 906 & 0.781 & 3.4 & 2.3 \\
\hline \multicolumn{13}{|l|}{ Rees (11) 2008} \\
\hline Asian & 817 & 89 & 346 & 382 & 0.726 & 435 & 41 & 153 & 241 & 0.0791 & 32.1 & 27.0 \\
\hline \multicolumn{13}{|l|}{ Ren (12) 2008} \\
\hline Asian & 500 & 0 & 9 & 490 & 0.839 & 500 & 0 & 9 & 490 & 0.839 & 0.9 & 0.9 \\
\hline \multicolumn{13}{|l|}{ Sanghera (13) 2008} \\
\hline Asian & 556 & 81 & 248 & 227 & 0.324 & 537 & 67 & 219 & 242 & 0.118 & 36.9 & 33.4 \\
\hline \multicolumn{13}{|l|}{ Cruz (9) 2010} \\
\hline Caucasian & 519 & 12 & 135 & 372 & 0.952 & 547 & 8 & 113 & 426 & 0.021 & 15.3 & 11.8 \\
\hline \multicolumn{13}{|l|}{ Gupta (10) 2010} \\
\hline Asian & 219 & 40 & 87 & 64 & 0.304 & 184 & 26 & 64 & 68 & 0.107 & 43.7 & 36.7 \\
\hline \multicolumn{13}{|c|}{ Martinez-Gomez (7) 2011} \\
\hline Caucasian & 719 & 10 & 147 & 562 & 0.912 & 746 & 10 & 151 & 585 & 0.942 & 15.6 & 11.4 \\
\hline \multicolumn{13}{|l|}{ Dabelea (8) 2011} \\
\hline Caucasian & 86 & 10 & 28 & 48 & 0.077 & 608 & 49 & 237 & 322 & 0.562 & 32.0 & 27.5 \\
\hline American & 154 & 16 & 63 & 75 & 0.610 & 391 & 28 & 164 & 199 & 0.461 & 31.0 & 28.0 \\
\hline \multicolumn{13}{|l|}{ Turki (2) 2013} \\
\hline Caucasian & 900 & 154 & 430 & 311 & 0.797 & 875 & 101 & 353 & 424 & 0.038 & 41.0 & 34.0 \\
\hline \multicolumn{13}{|l|}{ Nemr (3) 2012} \\
\hline Asian & 691 & 159 & 345 & 187 & 0.996 & 919 & 113 & 418 & 388 & 0.979 & 48.0 & 35.0 \\
\hline \multicolumn{13}{|l|}{ Alami (4) 2012} \\
\hline Asian & 221 & 38 & 95 & 88 & 0.163 & 235 & 25 & 92 & 118 & 0.272 & 38.7 & 30.2 \\
\hline \multicolumn{13}{|l|}{ Kalnina (6) 2012} \\
\hline European & 1032 & 55 & 361 & 616 & 0.823 & 1079 & 37 & 322 & 720 & 0.892 & 22.8 & 18.4 \\
\hline \multicolumn{13}{|l|}{ Ciccacci (5) 2012} \\
\hline European & 154 & 32 & 70 & 52 & 0.350 & 182 & 19 & 80 & 83 & 0.966 & 44.0 & 32.0 \\
\hline
\end{tabular}

HWE $=$ Hardy-Weinberg equilibrium.

rs290487, and rs11196218) in TCF7L2 polymorphisms and the risk for T2DM in the East-Asian population (36). However, this meta-analysis involved only 5 articles about the East Asian population published before 2008 . In addition, 11 studies $(2-10,13,28)$ examining the global population were published after the aforementioned meta-analyses. Therefore, a meta-analysis is currently needed to assess the associations between rs 12255372 polymorphisms and the susceptibility to T2DM in the global population. The aim of the present study was to evaluate the association of rs12255372 with T2DM by performing a meta-analysis of 34,076 cases and 36,192 controls.

\section{Research design and methods}

\section{Publication search}

A systematic search of the US National Library of Medicine's PubMed, the Cochrane Library, and Embase databases was conducted for all genetic association studies on rs12255372 in the TCF7L2 gene and T2DM published from 2006 [when the initial study reporting the association between rs12255372 and T2DM was published (31)] to 2012. The language was limited to English. The following search terms were used in our metaanalysis: 'rs12255372', 'TCF7L2', 'T2DM/T2D', and 'genetic polymorphism'. 


\section{Inclusion criteria}

We used the following criteria to select our literature: 1) original papers, 2) case-control studies, 3) studies that provided raw data for genotypic distribution or allele frequencies. A total of 41 papers were identified as potential candidates; 6 of them did not analyze rs12255372 and 2 did not concern the association between rs12255372 and T2DM and were excluded. Therefore, a total of 33 manuscripts were included in the final meta-analysis (2-34).

\section{Data extraction}

The following data were extracted independently from the articles by 2 of the authors (J. Wang and J. Zhang): first author's name, publication date, ethnicity, the sample size of cases and controls, allele frequencies, and numbers of each genotype.

\section{Statistical analysis}

To perform the meta-analysis, we used the METAN module within the STATA 11.0 software (USA). The strength of association between rs 12255372 and the risk of T2DM was measured by odds ratios (ORs) with $95 \%$ confidence intervals $(\mathrm{Cl})$ via the Z-test. The heterogeneity index $\left(I^{2}, 0-100\right)$ was applied to assess heterogeneity among the studies (37). If $I^{2}$ is above $50 \%$, there is high heterogeneity between studies based on the Cochrane reviewer's handbook 4.2 .2 (38). The fixed-effect model with the Mantel-Haenszel method was applied if heterogeneity was not an issue in the studies (39). Otherwise the random model using the DerSimonian and Laird method was used (40). Subgroup analyses were performed according to ethnicity (European, Caucasian, Asian, African, and American). A funnel plot was constructed to display the potential publication bias, in

Table 2. Results of meta-analysis for rs 12255372 and type 2 diabetes.

\begin{tabular}{|c|c|c|c|c|c|c|}
\hline \multirow[t]{2}{*}{ Comparison } & \multirow[t]{2}{*}{ No. of studies } & \multirow[t]{2}{*}{ Odds ratio } & \multirow{2}{*}{$\begin{array}{l}95 \% \text { confidence } \\
\text { interval }\end{array}$} & \multicolumn{3}{|c|}{ Heterogeneity } \\
\hline & & & & $Q$ & $P$ & $l^{2}(\%)$ \\
\hline $\mathrm{T}$ allele vs $\mathrm{G}$ allele & 42 & 1.387 & $1.351-1.424$ & 80.11 & $<0.001$ & 48.8 \\
\hline Europeans & 6 & 1.386 & $1.290-1.488$ & 2.43 & 0.787 & 0.0 \\
\hline Caucasians & 14 & 1.401 & $1.346-1.448$ & 38.50 & $<0.001$ & 66.2 \\
\hline Asians & 17 & 1.409 & $1.324-1.498$ & 20.57 & 0.196 & 22.2 \\
\hline Africans & 2 & 1.082 & $0.938-1.249$ & 3.64 & 0.057 & 72.5 \\
\hline Americans & 3 & 1.362 & $1.136-1.634$ & 2.86 & 0.240 & 30.0 \\
\hline TT vs GG & 38 & 1.933 & $1.815-2.057$ & 63.33 & 0.004 & 41.6 \\
\hline Europeans & 6 & 1.927 & $1.602-2.319$ & 2.30 & 0.806 & 0.0 \\
\hline Caucasians & 14 & 2.016 & $1.867-2.177$ & 32.25 & 0.002 & 59.7 \\
\hline Asians & 14 & 1.839 & $1.587-2.132$ & 18.79 & 0.130 & 30.8 \\
\hline Africans & 2 & 1.186 & $0.842-1.670$ & 0.23 & 0.633 & 0.0 \\
\hline Americans & 2 & 1.634 & $0.919-2.906$ & 0.15 & 0.696 & 0.0 \\
\hline GT vs GG & 42 & 1.363 & $1.315-1.413$ & 69.19 & 0.004 & 40.7 \\
\hline Europeans & 6 & 1.367 & $1.247-1.499$ & 3.23 & 0.664 & 0.0 \\
\hline Caucasians & 14 & 1.377 & $1.315-1.442$ & 33.38 & 0.001 & 61.1 \\
\hline Asians & 17 & 1.431 & $1.318-1.553$ & 8.68 & 0.926 & 0.0 \\
\hline Africans & 2 & 1.078 & $0.888-1.309$ & 7.99 & 0.005 & 87.5 \\
\hline Americans & 3 & 0.932 & $0.722-1.202$ & 2.0 & 0.840 & 0.0 \\
\hline Dominant model & 42 & 1.425 & $1.344-1.510$ & 91.61 & 0.000 & 55.2 \\
\hline Europeans & 6 & 1.437 & $1.316-1.568$ & 2.49 & 0.778 & 73.2 \\
\hline Caucasians & 14 & 1.462 & $1.333-1.605$ & 48.47 & $<0.001$ & 0.0 \\
\hline Asians & 17 & 1.490 & $1.377-1.611$ & 14.46 & 0.564 & 85.4 \\
\hline Africans & 2 & 1.022 & $0.613-1.705$ & 6.87 & 0.009 & 0.0 \\
\hline Americans & 3 & 0.994 & $0.778-1.270$ & 0.51 & 0.776 & 55.2 \\
\hline Recessive model & 38 & 1.659 & $1.563-1.761$ & 43.84 & 0.204 & 15.6 \\
\hline Europeans & 6 & 1.700 & $1.421-2.033$ & 2.70 & 0.746 & 0.0 \\
\hline Caucasians & 14 & 1.711 & $1.590-1.841$ & 20.78 & 0.077 & 37.5 \\
\hline Asians & 14 & 1.568 & $1.364-1.802$ & 13.85 & 0.385 & 6.1 \\
\hline Africans & 2 & 1.143 & $0.822-1.589$ & 0.08 & 0.777 & 0.0 \\
\hline Americans & 2 & 1.629 & $1.932-2.849$ & 0.20 & 0.656 & 0.0 \\
\hline
\end{tabular}


which OR (in log units) was on the x-axis and the standard error of log OR was on the y-axis. If there is any publication bias, the funnel plot will support the presence of asymmetry. We assessed the funnel plot asymmetry by the Egger test. Sensitivity analysis was performed by omitting one study at a time and calculating the pooled ORs for the remaining studies.

\section{Results}

\section{Description of the studies}

The electronic search yielded 41 potentially relevant articles on the association between rs12255372 and T2DM; however, only 33 papers including 42 studies met our inclusion criteria and were included in the final metaanalysis (2-34). Table 1 lists the distribution of the rs12255372 genotypes in studies on the TCF7L2 gene and susceptibility to T2DM. Among the 42 studies with 34,076 cases and 36,192 controls [ 3 studies in the paper by Grant et al. (31), 3 in the paper by Horikoshi et al. (17), 3 in the paper by Humphries et al. (33), 3 in the paper by Miyake et al. (14), and 2 in the paper by Dabelea et al. (8)], 6 studies were about Europeans, 14 about Caucasians, 17 about Asians, 2 about Africans, and 3 about Americans.

\section{Results of the meta-analysis}

Table 2 lists the main results of our meta-analysis, in which we analyzed OR for the risk allele $\mathrm{T}$, the TT genotype, the GT genotype, the dominant model, and the recessive model. The heterogeneity test $\left(I^{2}>50 \%\right)$ revealed high heterogeneity between studies for the dominant model. A random effect model was applied and generated a combined allelic OR $=1.425$ for the dominant model of $12255372(95 \% \mathrm{Cl}=1.344-1.510)$. Light heterogeneity was found between studies in other genetic models by $P^{2}$, and a fixed-effect model was applied for meta-analysis (for the risk allele $\mathrm{T}$ : $\mathrm{OR}=1.387$, $95 \% \mathrm{Cl}=1.351-1.424$; for $\mathrm{TT}$ vs GG: OR $=1.933$, $95 \% \mathrm{Cl}=1.815-2.057$; for GT vs GG: OR $=1.363$, $95 \% \mathrm{Cl}=1.315-1.413$; for the recessive model: OR $=$ $1.659,95 \% \mathrm{Cl}=1.563-1.761)$. Figures 1 to 5 present the results of meta-analysis for rs 12255372 from a pooled sample of 34,076 T2DM subjects and 36,192 control subjects from 42 studies.

\section{Subgroup analyses}

Subgroup analysis by ethnicity showed that all genotypes were significantly associated with T2DM for Europeans, Caucasians, and Asians; the risk allele $\mathrm{T}$ and the recessive model of rs 12255372 were associated with T2DM for the American population; neither genotype contributed to T2DM among Africans (see Table 2). The difference in ethnicity contributed to the heterogeneity. The studies on Caucasians involved more heterogeneity,

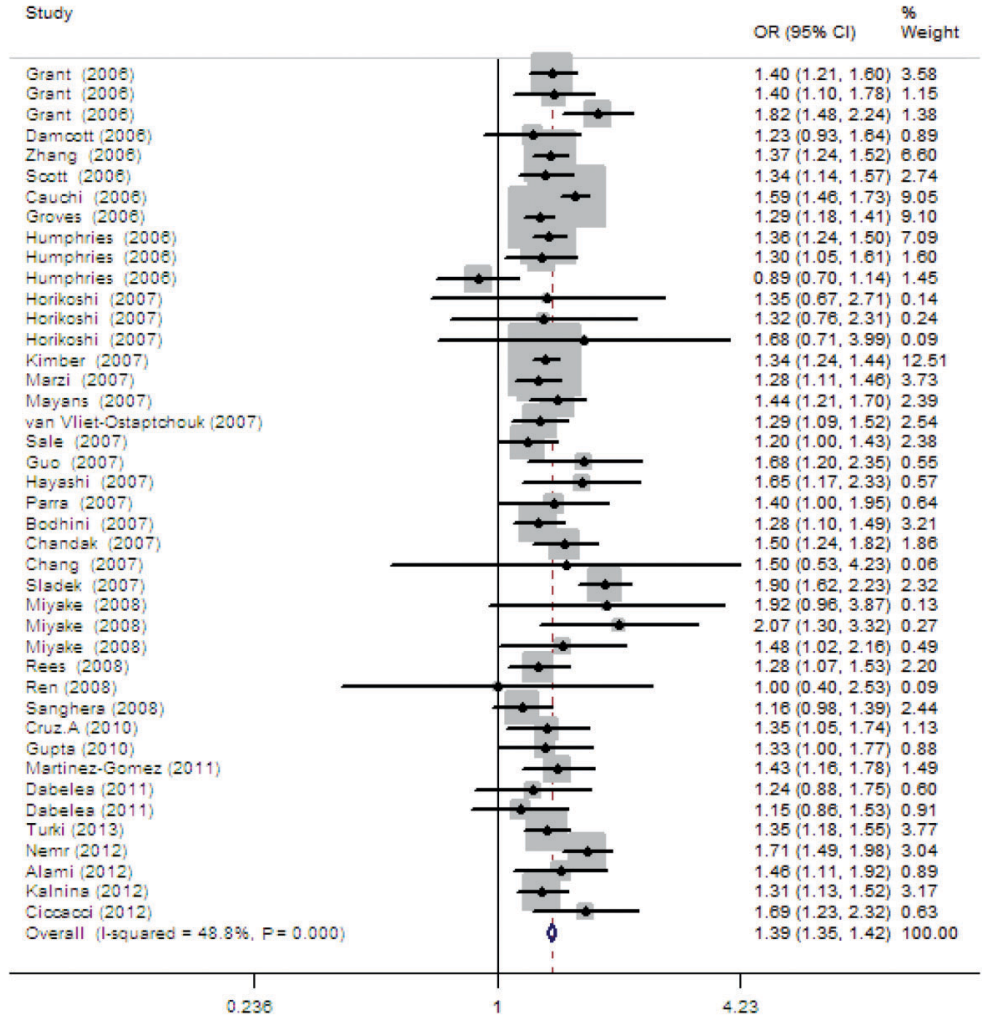

Figure 1. Meta-analysis of the association between type 2 diabetes and the risk allele T of rs12255372. 

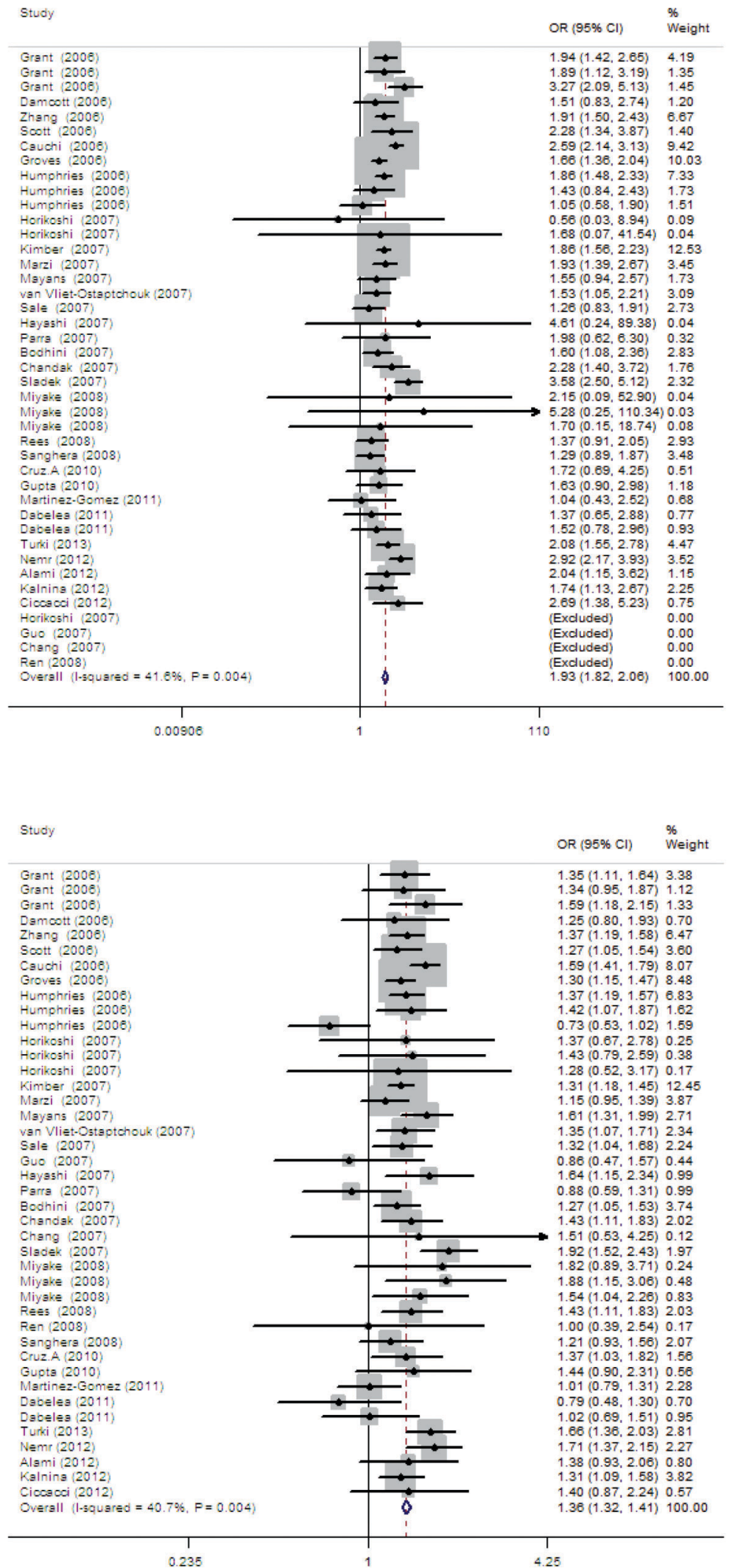

Figure 2. Meta-analysis of the association between type 2 diabetes and the TT genotype of rs12255372.
Figure 3. Meta-analysis of the association between type 2 diabetes and the GT genotype of rs 12255372 . 

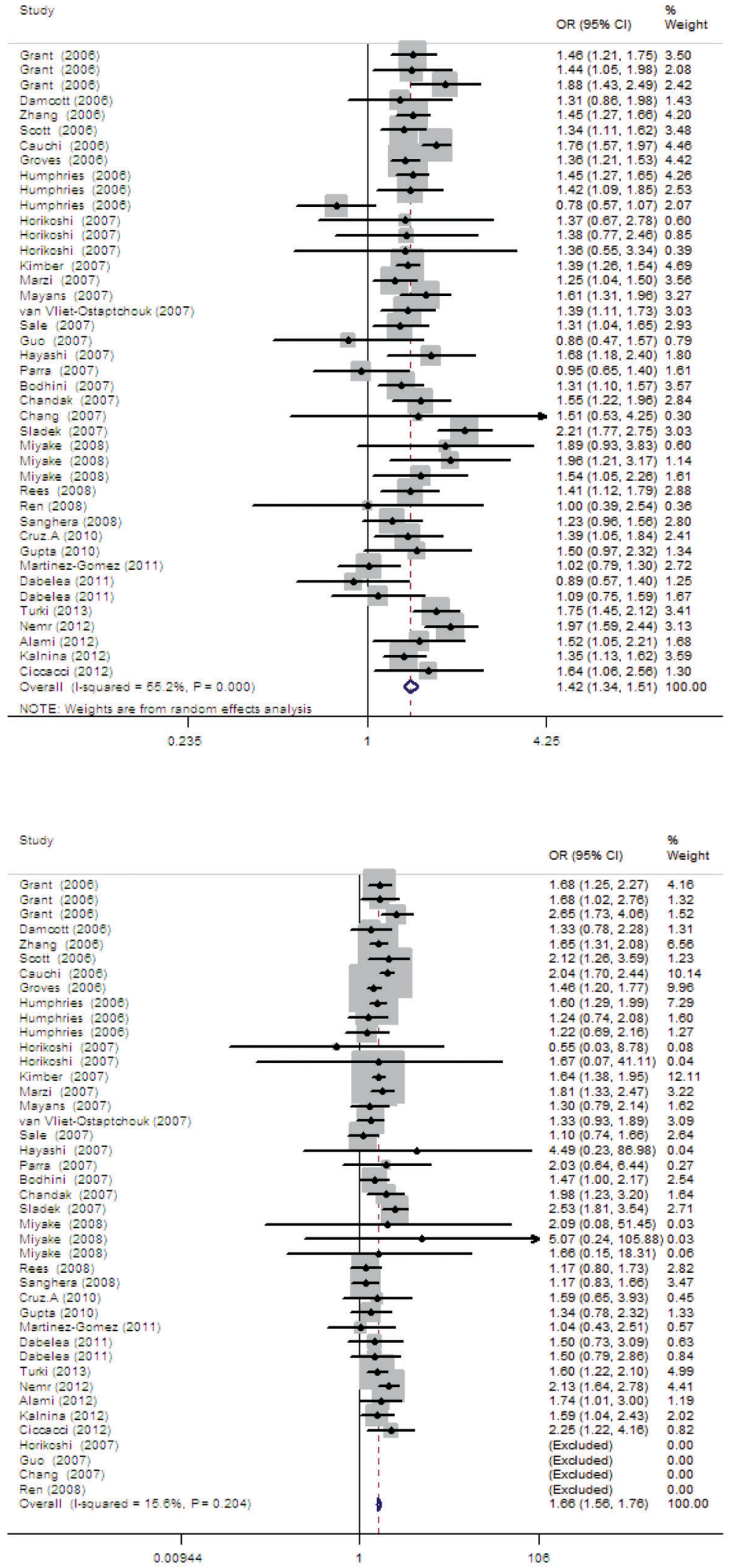

Figure 4. Meta-analysis of the association between type 2 diabetes and the dominant model of rs12255372.
Figure 5. Meta-analysis of the association between type 2 diabetes and the recessive model of rs12255372. 
Table 3. Results of the Egger test.

\begin{tabular}{lcc}
\hline SNP & Genetic models & PE \\
\hline rs12255372 & T/G & 0.610 \\
& TT/GG & 0.588 \\
& GT/GG & 0.658 \\
& Dominant model & 0.504 \\
& Recessive model & 0.912 \\
\hline
\end{tabular}

$\mathrm{SNP}=$ single nucleotide polymorphism; $\mathrm{PE}=\mathrm{P}$ values for publication bias from the Egger test.

with the complex compositions possibly being the main reason for this heterogeneity.

\section{Publication bias}

The funnel plot and the Egger test were performed to assess the publication bias of the literature. We displayed the funnel plot for ORs, and no evidence of obvious asymmetry was observed. All $\mathrm{P}$ values were higher than 0.05 according to the Egger test (see Table 3), and therefore no publication bias was found. Figure 6 presents Begg's funnel plots of publication bias.

\section{Sensitivity analyses}

We performed sensitivity analysis by omitting one study at a time and calculating the pooled ORs for the remaining studies. The results showed that none of the individual studies influenced the final conclusion. The sensitivity analysis indicated that our meta-analysis had reliable and stable results.

\section{Discussion}

TCF7L2 encodes an enteroendocrine transcription factor that controls the transcription of the proglucagon gene, which encodes both glucagon and glucagon-like peptide 1 (GLP-1). GLP-1 is a 30-amino acid peptide hormone produced by the intestinal epithelial endocrine Lcells by differential processing of proglucagon, the gene, which is expressed in these cells. The main actions of GLP-1 are to stimulate insulin secretion and to inhibit glucagon secretion, thereby contributing to limiting postprandial glucose excursions. Therefore, it has been suggested that polymorphisms in the TCF7L2 gene may affect the risk of T2DM by regulating the expression of GLP-1.

After a common microsatellite in the TCF7L2 gene region (DG10S478) was found to be associated with T2DM and this finding was convincingly replicated by Grant in 2006 (31) by using non-coding SNPs rs7903146, rs12255372, and rs11196205 that were in strong linkage disequilibrium with DG10S478, many other epidemiological study groups have detected a consistent association between these SNPs and T2DM in different ethnic populations including Japanese, Chinese, Americans, and Asian Indians. However, although the association between rs12255372 and T2DM has been evaluated by many research groups, the results remain conflicting rather than conclusive. These conflicting results indicated that a meta-analysis would be essential in order to validate the association between rs12255372 and T2DM.

Our meta-analysis included 33 papers for rs 12255372; the results showed that the variant allele $T$, the TT genotype, the GT genotype, the dominant model, and the recessive model were all strongly associated with T2DM in the global population. Because the risk allele frequency of rs12255372 differed greatly among ethnicities (about 0.000 to 0.029 for Asians, $0.217-0.500$ for Europeans, and 0.267-0.274 for Sub-Saharan Africans), we performed subgroup analyses according to ethnicity. The results suggested that the role of rs12255372 in T2DM may be mediated by ethnicity. For Europeans, Caucasians, and Asians, all genotypes and the risk allele $\mathrm{T}$ were significantly associated with T2DM, while for Americans, only the risk allele $T$ and the recessive model could notably increase the risk of T2DM, suggesting that, although the risk allele $\mathrm{T}$ may increase the risk of incidence of T2DM, both copies of the mutant allele could achieve the goal, and a copy of the wild allele could be sufficient to provide protection. In contrast, for Africans, neither genotype contributed to the risk of T2DM. First, the differences in ethnicity and region may contribute to the strong heterogeneity of the genetic phenotype of T2DM. Second, the lack of original data in the studies reviewed limited our further evaluation of potential interactions of rs12255372 and T2DM, and confounders such as gender, age, and body mass index (BMI) may have contributed to the different results. Third, since studies on Africans were relatively rare in our metaanalysis, this may have reduced the power to detect an association of rs 12255372 with T2DM in Africans.

In multiple ethnicities, the differences were reflected not only in the distributions of minor allele frequency in rs12255372 but also in the linkage disequilibrium (LD) structure between rs12255372 and rs7903146. Table 4 summarizes the pairwise LD coefficients $r^{2}$ and D' between these two SNPs in different populations based on the data from HapMap (HapMap Data Rel 27 Phasell+III, Feb09, on NCBI B36 assembly, dbSNP b126). The results showed that rs12255372 and rs7903146 are in relatively strong LD in Europeans, and therefore the effect of rs12255372 is not independent. rs7903146 is known to be the strongest SNP for the risk of T2DM, and therefore the interaction between these two SNPs may be the key point for the association with T2DM. More representative and comprehensive studies on populations of different ethnic backgrounds are needed to clarify the mechanisms and underlying genetic effects of these two SNPs for T2DM in the global population. 

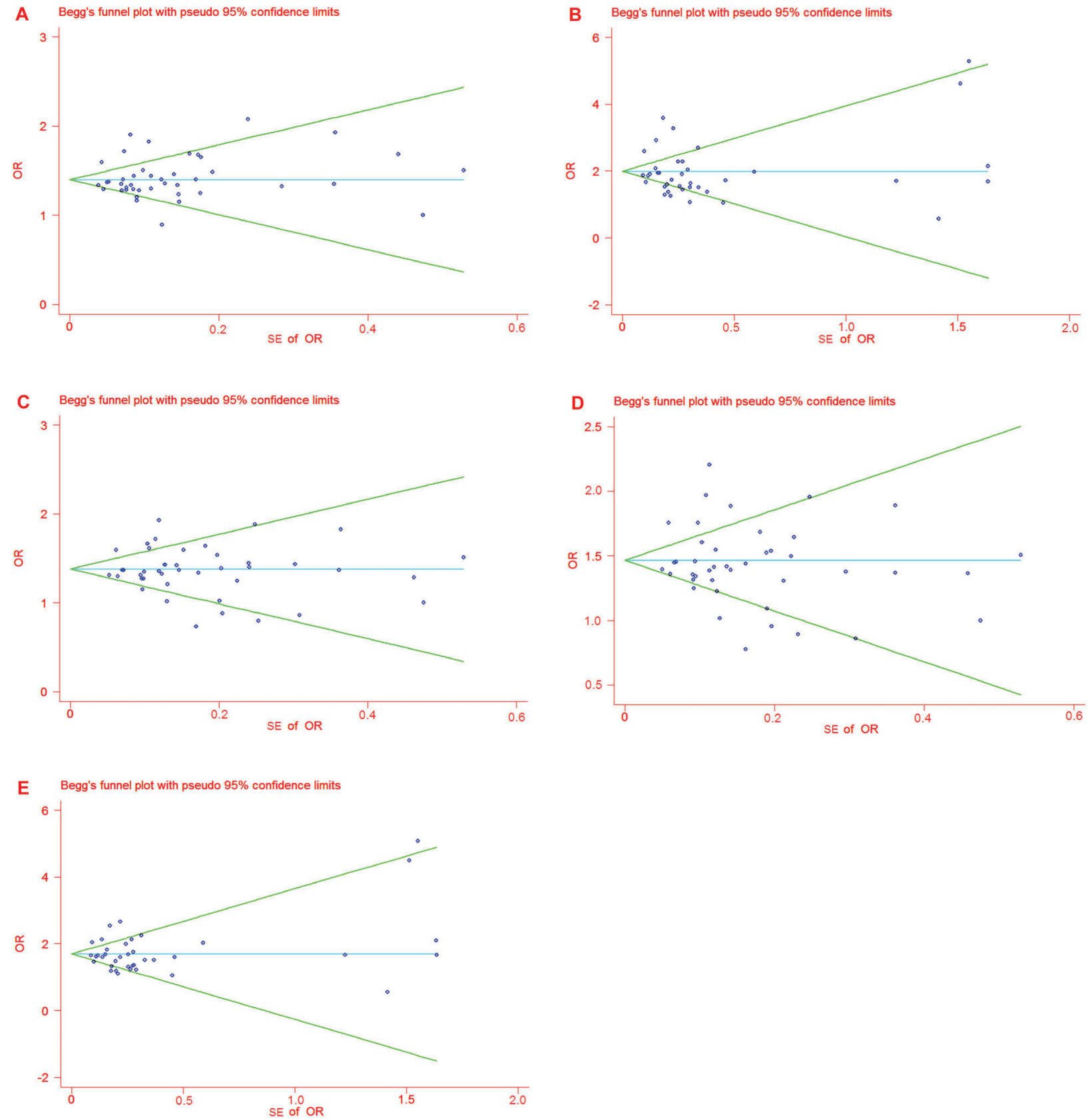

Figure 6. Funnel plot analyses for odds ratios. Panel A, Funnel plot analysis for odds ratios of allele $\mathrm{T}$ compared with allele $\mathrm{G}$ in the studies analyzed. Panel B, Funnel plot analysis for odds ratios of genotype TT compared with genotype GG in the studies analyzed. Panel C, Funnel plot analysis for odds ratios of genotype GT compared with genotype GG in the studies analyzed. Panel $D$, Funnel plot analysis for odds ratios of the dominant model. Panel E, Funnel plot analysis for odds ratios of the recessive model. 
Table 4. Linkage disequilibrium (as $r^{2}$ and D') between rs12255372 and rs7903146 of the TCF7L2 gene in multiple ethnicities.

\begin{tabular}{cccc}
\hline & CEU & YRI & CHB + JPT \\
\hline$r^{2}$ & 0.746 & 0.001 & 0.114 \\
$D^{\prime}$ & 0.948 & 0.075 & 0.479 \\
\hline
\end{tabular}

$\mathrm{CEU}=$ Europeans; $\mathrm{YRI}=$ Sub-Saharan Africans; $\mathrm{CHB}+\mathrm{JPT}=$ Chinese and Japanese.

However, due to the really weak LD structure between them, and coupled to the lower minor allele frequency, the effect of rs12255372 for the risk of T2DM in Sub-Saharan Africans and East Asians was quite small.

Hardy-Weinberg equilibrium is a principle showing how representative the samples are. Violations of HardyWeinberg assumptions can cause deviations from expectation. In our 33 eligible articles, the genotypes in both cases and controls almost conformed to the HardyWeinberg principle.

Heterogeneity is a potential problem when interpreting the results of meta-analysis. Our meta-analysis revealed high heterogeneity between studies for the dominant model $\left(I^{2}>50 \%\right)$. By subgroup analysis, we found that studies focusing on Caucasians exhibited more heterogeneity because of their complex composition. The differences in gender, age, and BMI among the studies,

\section{References}

1. American Diabetes Association. Screening for type 2 diabetes. Diabetes Care 2003; 26 (Suppl 1): S21-S24.

2. Turki A, Al-Zaben GS, Mtiraoui $\mathrm{N}$, Marmmuoch $\mathrm{H}$, Mahjoub T, Almawi WY. Transcription factor-7-like 2 gene variants are strongly associated with type 2 diabetes in Tunisian Arab subjects. Gene 2013; 513: 244-248, doi: 10.1016/ j.gene.2012.10.086.

3. Nemr R, Turki A, Echtay A, Al-Zaben GS, Daher HS, IraniHakime NA, et al. Transcription factor-7-like 2 gene variants are strongly associated with type 2 diabetes in Lebanese subjects. Diabetes Res Clin Pract 2012; 98: e23-e27, doi: 10.1016/j.diabres.2012.09.044.

4. Alami FM, Ahmadi M, Bazrafshan $\mathrm{H}$, Tabarraei $\mathrm{A}$, Khosravi A, Tabatabaiefar MA, et al. Association of the TCF7L2 rs $12255372(\mathrm{G} / \mathrm{T})$ variant with type 2 diabetes mellitus in an Iranian population. Genet Mol Biol 2012; 35: 413-417, doi: 10.1590/S1415-47572012005000029.

5. Ciccacci C, Di Fusco D, Cacciotti L, Morganti R, D'Amato C, Novelli G, et al. TCF7L2 gene polymorphisms and type 2 diabetes: association with diabetic retinopathy and cardiovascular autonomic neuropathy. Acta Diabetol 2012 (Epub ahead of print).

6. Kalnina I, Geldnere K, Tarasova L, Nikitina-Zake L, Peculis $R$, Fridmanis $D$, et al. Stronger association of common variants in TCF7L2 gene with nonobese type 2 diabetes in the Latvian population. Exp Clin Endocrinol Diabetes 2012; 120: 466-468, doi: 10.1055/s-0032-1306298. and the quality of the articles might also contribute to the heterogeneity.

Some limitations of this meta-analysis should be acknowledged. Because of the absence of detailed information about BMI, age, and gender in some studies, we did our research based on single-factor estimates without adjustment for the other risk factors mentioned above. On the other hand, our study also showed some strengths. First, the sample sizes of the studies included were relatively large, possibly reducing the influence of the low allele frequency. Second, our meta-analysis showed much better homogeneity, suggesting the uniform composition or character of our studies. Third, no publication bias was found in our meta-analysis by the funnel plot and the Egger test.

In summary, in this meta-analysis, by pooling all available qualified data of genetic studies on rs12255372 and T2DM, we confirmed that rs12255372 was significantly associated with susceptibility to T2DM in the global population, the risk allele and the genotypes could increase the risk of T2DM from 1.363- to 1.933-fold.

\section{Acknowledgments}

Research supported by grants from the China National Natural Science Foundation (contact \#81072359). We sincerely thank all the authors whose work was included in this meta-nalysis.

7. Martinez-Gomez LE, Cruz M, Martinez-Nava GA, MadridMarina V, Parra E, Garcia-Mena J, et al. A replication study of the IRS1, CAPN10, TCF7L2, and PPARG gene polymorphisms associated with type 2 diabetes in two different populations of Mexico. Ann Hum Genet 2011; 75: 612-620, doi: 10.1111/j.1469-1809.2011.00668.x.

8. Dabelea D, Dolan LM, D'Agostino R Jr, Hernandez AM, McAteer JB, Hamman RF, et al. Association testing of TCF7L2 polymorphisms with type 2 diabetes in multi-ethnic youth. Diabetologia 2011; 54: 535-539, doi: 10.1007/ s00125-010-1982-7.

9. Cruz M, Valladares-Salgado A, Garcia-Mena J, Ross K, Edwards M, Angeles-Martinez J, et al. Candidate gene association study conditioning on individual ancestry in patients with type 2 diabetes and metabolic syndrome from Mexico City. Diabetes Metab Res Rev 2010; 26: 261-270, doi: 10.1002/dmrr.1082.

10. Gupta V, Khadgawat R, Ng HK, Kumar S, Aggarwal A, Rao $\mathrm{VR}$, et al. A validation study of type 2 diabetes-related variants of the TCF7L2, HHEX, KCNJ11, and ADIPOQ genes in one endogamous ethnic group of north India. Ann Hum Genet 2010; 74: 361-368, doi: 10.1111/j.14691809.2010.00580.x.

11. Rees SD, Bellary S, Britten AC, O'Hare JP, Kumar S, Barnett $\mathrm{AH}$, et al. Common variants of the TCF7L2 gene are associated with increased risk of type 2 diabetes mellitus in a UK-resident South Asian population. BMC Med Genet 
2008; 9: 8, doi: 10.1186/1471-2350-9-8.

12. Ren $Q$, Han $X Y$, Wang $F$, Zhang $X Y$, Han LC, Luo YY, et al. Exon sequencing and association analysis of polymorphisms in TCF7L2 with type 2 diabetes in a Chinese population. Diabetologia 2008; 51: 1146-1152, doi: 10.1007/s00125-008-1039-3.

13. Sanghera DK, Nath SK, Ortega L, Gambarelli M, KimHoward X, Singh JR, et al. TCF7L2 polymorphisms are associated with type 2 diabetes in Khatri Sikhs from North India: genetic variation affects lipid levels. Ann Hum Genet 2008; 72: 499-509, doi: 10.1111/j.1469-1809.2008.00443.x.

14. Miyake K, Horikawa Y, Hara K, Yasuda K, Osawa H, Furuta $\mathrm{H}$, et al. Association of TCF7L2 polymorphisms with susceptibility to type 2 diabetes in 4,087 Japanese subjects. J Hum Genet 2008; 53: 174-180, doi: 10.1007/s10038-0070231-5.

15. Bodhini D, Radha V, Dhar M, Narayani N, Mohan V. The rs12255372(G/T) and rs7903146(C/T) polymorphisms of the TCF7L2 gene are associated with type 2 diabetes mellitus in Asian Indians. Metabolism 2007; 56: 1174-1178, doi: 10.1016/j.metabol.2007.04.012.

16. Chang YC, Chang TJ, Jiang YD, Kuo SS, Lee KC, Chiu KC, et al. Association study of the genetic polymorphisms of the transcription factor 7-like 2 (TCF7L2) gene and type 2 diabetes in the Chinese population. Diabetes 2007; 56: 2631-2637, doi: 10.2337/db07-0421.

17. Horikoshi M, Hara K, Ito C, Nagai R, Froguel $P$, Kadowaki T. A genetic variation of the transcription factor 7 -like 2 gene is associated with risk of type 2 diabetes in the Japanese population. Diabetologia 2007; 50: 747-751, doi: 10.1007/ s00125-006-0588-6.

18. van Vliet-Ostaptchouk JV, Shiri-Sverdlov R, Zhernakova A, Strengman $\mathrm{E}$, van Haeften TW, Hofker $\mathrm{MH}$, et al. Association of variants of transcription factor 7 -like 2 (TCF7L2) with susceptibility to type 2 diabetes in the Dutch Breda cohort. Diabetologia 2007; 50: 59-62, doi: 10.1007/s00125-006-0477-z.

19. Chandak GR, Janipalli CS, Bhaskar S, Kulkarni SR, Mohankrishna P, Hattersley AT, et al. Common variants in the TCF7L2 gene are strongly associated with type 2 diabetes mellitus in the Indian population. Diabetologia 2007; 50: 63-67, doi: 10.1007/s00125-006-0502-2.

20. Mayans S, Lackovic K, Lindgren P, Ruikka K, Agren A, Eliasson $M$, et al. TCF7L2 polymorphisms are associated with type 2 diabetes in northern Sweden. Eur J Hum Genet 2007; 15: 342-346, doi: 10.1038/sj.ejhg.5201773.

21. Hayashi $T$, Iwamoto $Y$, Kaku K, Hirose $H$, Maeda $S$. Replication study for the association of TCF7L2 with susceptibility to type 2 diabetes in a Japanese population. Diabetologia 2007; 50: 980-984, doi: 10.1007/s00125-0070618-z.

22. Sladek R, Rocheleau G, Rung J, Dina C, Shen L, Serre D, et al. A genome-wide association study identifies novel risk loci for type 2 diabetes. Nature 2007; 445: 881-885, doi: 10.1038/nature05616.

23. Sale MM, Smith SG, Mychaleckyj JC, Keene KL, Langefeld $C D$, Leak TS, et al. Variants of the transcription factor 7-like 2 (TCF7L2) gene are associated with type 2 diabetes in an African-American population enriched for nephropathy. Diabetes 2007; 56: 2638-2642, doi: 10.2337/db07-0012.

24. Guo T, Hanson RL, Traurig M, Muller YL, Ma L, Mack J, et al. TCF7L2 is not a major susceptibility gene for type 2 diabetes in Pima Indians: analysis of 3,501 individuals. Diabetes 2007; 56: 3082-3088, doi: 10.2337/db07-0621.

25. Kimber $\mathrm{CH}$, Doney AS, Pearson ER, McCarthy MI, Hattersley AT, Leese GP, et al. TCF7L2 in the Go-DARTS study: evidence for a gene dose effect on both diabetes susceptibility and control of glucose levels. Diabetologia 2007; 50: 1186-1191, doi: 10.1007/s00125-007-0661-9.

26. Marzi C, Huth C, Kolz M, Grallert H, Meisinger C, Wichmann $\mathrm{HE}$, et al. Variants of the transcription factor 7 -like 2 gene (TCF7L2) are strongly associated with type 2 diabetes but not with the metabolic syndrome in the MONICA/KORA surveys. Horm Metab Res 2007; 39: 46-52, doi: 10.1055/s2007-957345.

27. Parra EJ, Cameron E, Simmonds L, Valladares A, McKeigue $P$, Shriver $M$, et al. Association of TCF7L2 polymorphisms with type 2 diabetes in Mexico City. Clin Genet 2007; 71: 359-366, doi: 10.1111/j.13990004.2007.00780.x.

28. Damcott CM, Pollin TI, Reinhart LJ, Ott SH, Shen H, Silver $\mathrm{KD}$, et al. Polymorphisms in the transcription factor 7-like 2 (TCF7L2) gene are associated with type 2 diabetes in the Amish: replication and evidence for a role in both insulin secretion and insulin resistance. Diabetes 2006; 55: 26542659, doi: 10.2337/db06-0338.

29. Scott LJ, Bonnycastle LL, Willer CJ, Sprau AG, Jackson AU, Narisu $\mathrm{N}$, et al. Association of transcription factor 7-like 2 (TCF7L2) variants with type 2 diabetes in a Finnish sample. Diabetes 2006; 55: 2649-2653, doi: 10.2337/db06-0341.

30. Zhang C, Qi L, Hunter DJ, Meigs JB, Manson JE, van Dam RM, et al. Variant of transcription factor 7-like 2 (TCF7L2) gene and the risk of type 2 diabetes in large cohorts of U.S. women and men. Diabetes 2006; 55: 2645-2648, doi: 10.2337/db06-0643.

31. Grant SF, Thorleifsson G, Reynisdottir I, Benediktsson R, Manolescu A, Sainz J, et al. Variant of transcription factor 7like 2 (TCF7L2) gene confers risk of type 2 diabetes. Nat Genet 2006; 38: 320-323, doi: 10.1038/ng1732.

32. Groves CJ, Zeggini E, Minton J, Frayling TM, Weedon MN, Rayner NW, et al. Association analysis of 6,736 U.K. subjects provides replication and confirms TCF7L2 as a type 2 diabetes susceptibility gene with a substantial effect on individual risk. Diabetes 2006; 55: 2640-2644, doi: 10.2337/db06-0355.

33. Humphries SE, Gable D, Cooper JA, Ireland H, Stephens JW, Hurel SJ, et al. Common variants in the TCF7L2 gene and predisposition to type 2 diabetes in UK European Whites, Indian Asians and Afro-Caribbean men and women. J Mol Med 2006; 84: 1005-1014, doi: 10.1007/s00109-0060108-7.

34. Cauchi S, Meyre D, Dina C, Choquet H, Samson C, Gallina $\mathrm{S}$, et al. Transcription factor TCF7L2 genetic study in the French population: expression in human beta-cells and adipose tissue and strong association with type 2 diabetes. Diabetes 2006; 55: 2903-2908, doi: 10.2337/db06-0474.

35. Tong $\mathrm{Y}$, Lin $\mathrm{Y}$, Zhang $\mathrm{Y}$, Yang J, Zhang $\mathrm{Y}$, Liu $\mathrm{H}$, et al. Association between TCF7L2 gene polymorphisms and susceptibility to type 2 diabetes mellitus: a large Human Genome Epidemiology (HuGE) review and meta-analysis. BMC Med Genet 2009; 10: 15, doi: 10.1186/1471-2350-10-15

36. Luo $Y$, Wang $H$, Han $X$, Ren $Q$, Wang $F$, Zhang $X$, et al. 
Meta-analysis of the association between SNPs in TCF7L2 and type 2 diabetes in East Asian population. Diabetes Res Clin Pract 2009; 85: 139-146, doi: 10.1016/j.diabres. 2009.04.024.

37. Higgins JP, Thompson SG, Deeks JJ, Altman DG. Measuring inconsistency in meta-analyses. BMJ 2003; 327: 557-560, doi: 10.1136/bmj.327.7414.557.

38. Ling W, Farrell M, Ali R. Cochrane systematic reviews: time for an introduction and appraisal. Drug Alcohol Depend 2004; 73: 217-218, doi: 10.1016/j.drugalcdep.2003.11.003.

39. Mantel N, Haenszel W. Statistical aspects of the analysis of data from retrospective studies of disease. J Natl Cancer Inst 1959; 22: 719-748.

40. DerSimonian R, Laird N. Meta-analysis in clinical trials. Control Clin Trials 1986; 7: 177-188, doi: 10.1016/01972456(86)90046-2. 